\title{
Een relationele benadering van beheersing en vertrouwen binnen samenwerkingsrelaties
}

\author{
Reinald Minnaar, Paula van Veen-Dirks
}

\author{
Received 10 January 2019 | Accepted 2 March 2019 | Published 26 April 2019
}

\section{Samenvatting}

De studie die in dit artikel wordt beschreven, onderzoekt de relatie tussen contracten, beheersing en vertrouwen vanuit een relationeel perspectief. Dit relationele perspectief wordt inzichtelijk gemaakt met behulp van een casestudie van een specifieke uitbestedingsrelatie tussen een groot internationaal bedrijf (Semorg) en een aanbieder van facilitaire diensten (Fasorg). De casestudie laat niet alleen zien dat de contracten en de beheersingsstructuren doelbewust zijn ontworpen en opgesteld door topmanagers vanuit een functioneel perspectief, maar ook dat ze zelf zaken in gang kunnen zetten die vervolgens weer onverwachte gevolgen kunnen hebben (relationeel perspectief). In de casestudie bleek de oorspronkelijke contractuele oplossing, zoals die door onderhandeling door het topmanagement tot stand was gekomen, problematisch te zijn; het daaruit voortvloeiende contract en de in het contract opgenomen beheersingsstructuren veroorzaakten een proces van hercontractering dat uiteindelijk leidde tot veranderingen in de beheersing van en het vertrouwen binnen de relatie.

\section{Relevantie voor de praktijk}

Dit onderzoek heeft met name conceptuele relevantie voor de praktijk. Het laat partijen in een uitbestedingsrelatie reflecteren op specifieke beslissingen die worden genomen op een bepaald moment in de relatie. In het bijzonder kan het hen het inzicht geven dat het contract, beheersingsstructuren, en vertrouwen niet alleen te beschouwen zijn als instrumenten die worden gebruikt door mensen die het gedrag van anderen in het samenwerkingsverband willen beïnvloeden, maar ook als performatieve elementen die de betrokken partijen in de samenwerkingsrelatie aanzetten tot een bepaald gedrag en daarmee de relatie vormgeven. Ze dienen dan niet zozeer als het sluitstuk van de samenwerking maar eerder als startpunt voor samenwerking en ontwikkeling van vertrouwen.

\section{Trefwoorden}

Beheersing, vertrouwen, contracteren, samenwerkingsrelaties, relationeel

\section{Inleiding}

Samenwerkingsverbanden tussen bedrijven zijn gebaseerd op contracten, maar ook op vertrouwen, wat de onderlinge relatie tussen contracten, vertrouwen en beheersing interessant makt voor onderzoek (Tsamenyi et al. 2013). De literatuur over vertrouwen en beheersing kan vanuit een rationeel perspectief en een relationeel perspectief worden bestudeerd. Vanuit een rationeel perspectief worden vertrouwen en beheersing beschouwd als een oplossing voor beheersingsproblemen. Vertrouwen kan dan worden opgevat als een sociaal beheersingsmechanisme dat de behoefte aan formele beheersing vermindert (Dekker 2004). Vanuit een rationeel perspectief zijn zowel vertrouwen als contractuele garanties belangrijke beheersingsmechanismen die de risico's die verbonden zijn aan samenwerking verminderen en die daarmee ook de samenwerking in een partnerschap vergemakkelijken (Lui and Ngo 2004, p. 474). Vertrouwen wordt ook wel ingedeeld in dik en dun vertrouwen (Klein Woolthuis et al. 2005; Nooteboom 1996, 2002; Vosselman and Van der Meer-Kooistra 2009), waarbij dun vertrouwen voortkomt 
uit het gebruik van contracten en de daarin vastgelegde afspraken met betrekking tot beheersingsinstrumenten, bijvoorbeeld in de vorm van budgetten, scorecards en beloningssystemen, terwijl dik vertrouwen in de loop van de relatie wordt opgebouwd door relationele signalen waarmee samenwerkingspartners hun intenties ten aanzien van de samenwerking duidelijk maken. Deze relationele signalen vloeien voort uit rationele beslissingen die door de betrokken partijen worden genomen.

Een beperking van het rationele perspectief is dat het eraan voorbij gaat dat in werkelijkheid de vorm en verandering van zowel vertrouwen als beheersing vaak volgen uit complexe, onvoorspelbare, niet-lineaire en beperkt beïnvloedbare interacties tussen de verschillende betrokkenen bij de samenwerking (Chua and Mahama 2012). Een gerelateerd probleem is dat het rationele perspectief is gebaseerd op aannames van de economisch georiënteerde management control-literatuur, die de neiging heeft om medewerkers in een organisatie te reduceren tot agenten die alleen uit eigenbelang handelen (Van der Kolk et al. 2015).

Het doel van dit artikel is om naast dit rationele perspectief ook het relationele perspectief duidelijk voor het voetlicht te brengen. In dit relationele perspectief worden contracten, beheersingsstructuren, en vertrouwen vormgegeven en veranderd door en tijdens de interacties tussen de verschillende betrokkenen in de organisatie. Ze zijn daarmee ook niet meer alleen het directe gevolg van de beslissingen die door managers worden genomen die relatief ver van de dagelijkse gang van zaken af staan. Contracten en de daarin vastgelegde beheersingsstructuren kunnen daarmee dus uitstijgen boven de traditionele functionele eigenschappen zoals die zichtbaar worden gemakt en worden benadrukt in het rationele perspectief. Naast hun vermogen om een oplossing te bieden voor beheersingsproblemen en hun capaciteit om stabiliteit en orde aan te brengen, kunnen zij zelf dus ook dynamiek en verandering veroorzaken. Daarmee zijn de contracten en de beheersingsstructuren dan ook performatief. Performativiteit betekent hier dat modellen en theorieën zelf ook een invloed hebben op hoe de werkelijkheid er uit ziet, doordat ze mensen tot actie aanzetten (Revellino and Mouritsen 2015). De zogenaamde performativiteitsthesis beschrijft dat modellen en theorieën de wereld vormen in plaats van beschrijven (Callon 1998, 2007). Het begrip performativiteit stelt ons in staat om het contract, beheersingsstructuren en vertrouwen te beschouwen als elementen in een krachtenspel die de betrokken partijen in de relatie zelf actief aanzetten tot een bepaald gedrag. Contracten, beheersingsstructuren en vertrouwen kunnen performatief zijn in de zin dat ze helpen om de samenwerkingsrelatie op onverwachte manieren te creëren, te onderhouden en te wijzigen.

Dit artikel is als volgt opgebouwd. Paragraaf 2 geeft de theoretische basis voor de studie weer. Paragraaf 3 geeft informatie over de organisatie die in de casestudie is onderzocht en de onderzoeksmethode die is gebruikt. Paragraaf 4 beschrijft de resultaten van de casestudie. Deze beschrijving is erop gericht om duidelijk te maken hoe contracten en beheersingsstructuren performatief kunnen zijn in het opbouwen van vertrouwen en hoe ze de essentie van de relatie vormgeven. Tenslotte wordt in de discussie en conclusie paragraaf benadrukt hoe het onderzoek bijdraagt aan de management accounting literatuur.

\section{Theoretische basis}

\subsection{Een relationeel perspectief ten opzichte van een rationeel perspectief}

Essentieel voor een relationeel perspectief is dat het niet in de eerste plaats gericht is op de entiteiten zelf, maar op de verbindingen tussen de entiteiten. In het rationele perspectief staan de entiteiten zelf voorop en contracten en de daarin opgenomen beheersingsstructuren worden beschouwd als ondergeschikt aan de besluitvorming door mensen. Hun functie is om orde en stabiliteit te bieden. $\mathrm{Zij}$ zijn het gevolg van bestuurlijke besluitvorming en als zodanig bieden ze oplossingen voor coördinatieproblemen en voor mogelijk opportunistisch handelen door de samenwerkingspartner (Dekker 2004; Vosselman and Van der Meer-Kooistra 2009). Nadat managers door onderhandelingen het contract hebben afgesloten, dienen het contract en de beheersingsstructuren als instrumenten om de relatie vanaf een afstand te kunnen beheersen.

Vanuit een relationeel perspectief worden het contract en de beheersingsstructuren gevormd en veranderd in een netwerk van verbindingen tussen verschillende betrokkenen. Hoewel contracten hierbij nog steeds beschouwd kunnen worden als het resultaat van onderhandelingen die op een zekere afstand van de dagelijkse gang van zaken hebben plaatsgevonden, worden ze volgens dit perspectief in werking gesteld door de interactie waarmee de betrokken partijen vormgeven aan de dagelijkse praktijk. Contracten en de bijbehorende beheersingsstructuren worden hierbij niet gezien als eenvoudige oplossingen die probleemloos en onomwonden worden doorgevoerd, maar als belangrijke krachten die in het speelveld van de samenwerkingsrelatie een mobiliserende werking kunnen hebben. In die hoedanigheid kunnen zij leiden tot onverwachte en onvoorspelbare gevolgen en zijn zij zelf aan verandering onderhevig.

\subsection{Contracten, beheersing en vertrouwen in relaties tussen bedrijven}

In de management accounting-discipline is de onderlinge relatie tussen contracten beheersing en vertrouwen al jaren onderwerp van onderzoek. Sommige bijdragen zijn conceptueel van aard (Tomkins 2001; Vosselman and Van der Meer-Kooistra 2009), sommige bieden een overzicht van eerder onderzoek, terwijl andere betrekking hebben op onderzoek naar de beheersing van specifieke soorten samenwerkingsrelaties (Cäker 2008; Emsley and Kidon 2007; Langfield-Smith and Smith 2003; Thrane and Hald 2006). Weer andere onderzoekers bestuderen de beheersingssystemen die worden gebruikt in een netwerk van relaties (Chua 
and Mahama 2007; Håkansson and Lind 2004; Mahama and Chua 2016; Van Veen-Dirks and Verdaasdonk 2009).

Rationele en relationele perspectieven verschillen in hun conceptualisering van de onderlinge relaties tussen contracten, beheersingsstructuren en vertrouwen. Tot op zekere hoogte kan vertrouwen worden beschouwd als een direct gevolg van de onderhandelingen over een contract. Vanuit een rationeel perspectief is dit een intentioneel proces waarbij onderscheid kan worden gemaakt tussen dun vertrouwen (vertrouwen op basis van afspraken in het contract) en dik vertrouwen (vertrouwen op basis van relationele signalering) (Vosselman and Van der Meer-Kooistra 2009). De uit onderhandelingen voortvloeiende contractuele verplichtingen vormen de basis van waaruit de betrokken partijen dun vertrouwen kunnen opbouwen. Dit dunne vertrouwen dient als compensatie voor de twijfels die doorgaans bestaan met betrekking tot het gedrag van de andere partij in de samenwerkingsrelatie en biedt daarmee de mogelijkheid om tot samenwerking te komen. Dun vertrouwen is dus gebaseerd op het contract dat op zijn beurt weer is ingebed in het institutionele vertrouwen dat volgt uit de juridische en sociale context van de samenwerkingsrelatie.

Dun vertrouwen kan een basis bieden voor een vorm van zelfregulering, vanwege de onvermijdbare onvolledigheid van het contract; enige mate van onzekerheid zal, ook met een contract, altijd blijven bestaan. Deze zelfregulering kan plaatsvinden in de vorm van relationele signalen waarmee intenties met betrekking tot de samenwerking worden gecommuniceerd en dit kan dan vervolgens resulteren in dik vertrouwen. Net als bij dun vertrouwen, komt dik vertrouwen uiteindelijk ook voort uit bestuurlijke beslissingen waarbij managers vrijwillig besluiten om relationele signalen af te geven die leiden tot een toename van dik vertrouwen en daarmee tot een florerende samenwerking.

Ook vanuit een relationeel perspectief gezien hangen het contract en de daarin opgenomen afspraken met betrekking tot beheersingsstructuren nauw samen met het vergroten (of verkleinen) van vertrouwen. Vertrouwen kan circuleren in het netwerk waar ook het contract en de beheersingsstructuren deel van uitmaken. Het is een mogelijk maar ook onvoorspelbaar gevolg van de interacties die plaatsvinden in het netwerk. Deze visie verschilt wezenlijk van de visie die wordt uitgedragen binnen het rationele perspectief, waarin vertrouwen het voorspelbare en duidelijke gevolg is van bestuurlijke beslissingen. Vanuit een relationeel perspectief is vertrouwen het gevolg van een projectie van een emotionele waarde of intentie op iets of iemand anders in het netwerk. Vertrouwen is daarmee dus een gevolg van de interacties in een netwerk dat de samenwerkingsrelatie tussen bedrijven vormt.

Dit artikel bekijkt samenwerkingsrelaties tussen bedrijven voornamelijk vanuit het relationele perspectief. Het doel van het artikel is om te komen tot verdere theorievorming ten aanzien van de wijze waarop het contract en beheersingsstructuren performatief kunnen zijn zowel in de vorming en de verdere ontwikkeling van vertrouwen als in het verminderen van vertrouwen.

\section{Casusbeschrijving en onderzoeksmethodologie}

Het onderzoek richt zich op de uitbestedingsrelatie tussen Semorg en Fasorg (pseudoniemen). Semorg is een toonaangevende industriële onderneming in halfgeleiders en software voor tv's, identificatie-toepassingen, mobiele telefoons, auto's en andere elektronische apparaten. Semorg is opgericht door Lecorg (pseudoniem) en heeft een hoofdkantoor in Nederland en fabrieken in verschillende steden. Fasorg is een Brits-Nederlandse organisatie met specialistische kennis en ervaring over het beheren van facilitaire diensten.

Bij de uitbesteding van het facilitair management zijn Fasorg, verschillende afdelingen van Semorg en de externe leveranciers van facilitaire diensten betrokken. Dit onderzoek richt zich op de uitbestedingsrelatie tussen Semorg en Fasorg. Hoe de partijen zich tot elkaar verhouden is weergegeven in figuur 1 .

Figuur 1. De organisatie van het facilitaire management bij Semorg.

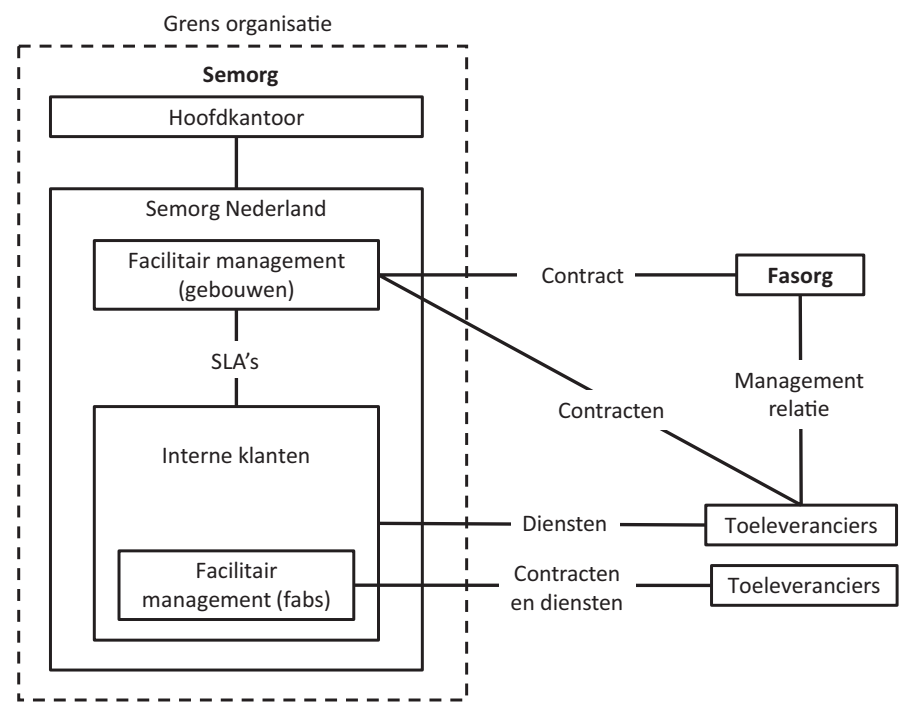


Binnen Semorg is een afdeling facilitair management (FM) verantwoordelijk voor de gebouwen. Het operationele beheer van deze building services is uitbesteed aan Fasorg. Semorg sluit service level agreements (SLA's) af met interne klanten, terwijl Fasorg de levering van de facilitaire diensten aan haar interne klanten van de verschillende leveranciers coördineert. Echter, niet alle coördinatietaken van de facilitaire diensten worden uitbesteed. Sommige complexe en zeer specifieke onderhoudsdiensten ten behoeve van de fabricageafdelingen worden beheerd door een aparte interne facilitaire afdeling. Deze afdeling koopt ook diensten van externe leveranciers in, maar beheert de levering van de diensten zelf. De managers van de facilitaire managementafdelingen leggen direct verantwoording af aan de directie van Semorg.

De relatie tussen Semorg en Fasorg begon met een vierjarig contract tussen Lecorg en Fasorg. Toen het contract werd ondertekend, was Semorg een business unit van Lecorg, maar niet één van de onderhandelende en contracterende partijen; het contract werd op het directieniveau van Lecorg afgesloten. Dit directieniveau stond dus enigszins op afstand van het netwerk waar de activiteiten in de uitbestedingsrelatie plaatsvonden. Vrij snel daarna ging Semorg verder als een onafhankelijke organisatie. Omdat Semorg's facilitaire managers ontevreden waren over het contract, werd een nieuwe facilitair managementdirecteur aangetrokken die het contract ging herzien. Deze herziening markeert het begin van onze studie naar de ontwikkelingen in de uitbestedingsrelatie.

Deze ontwikkelingen worden weergegeven in figuur 2. In het kader van het doel van dit onderzoek is vooral de periode van belang waarin het originele en het vernieuwde contract een rol hebben gespeeld in de ontwikkeling van de relatie. Tevens werd gedurende deze periode vertrouwen belangrijker.

Figuur 2. Tijdlijn van uitbestedingsrelatie tussen Semorg en Fasorg.

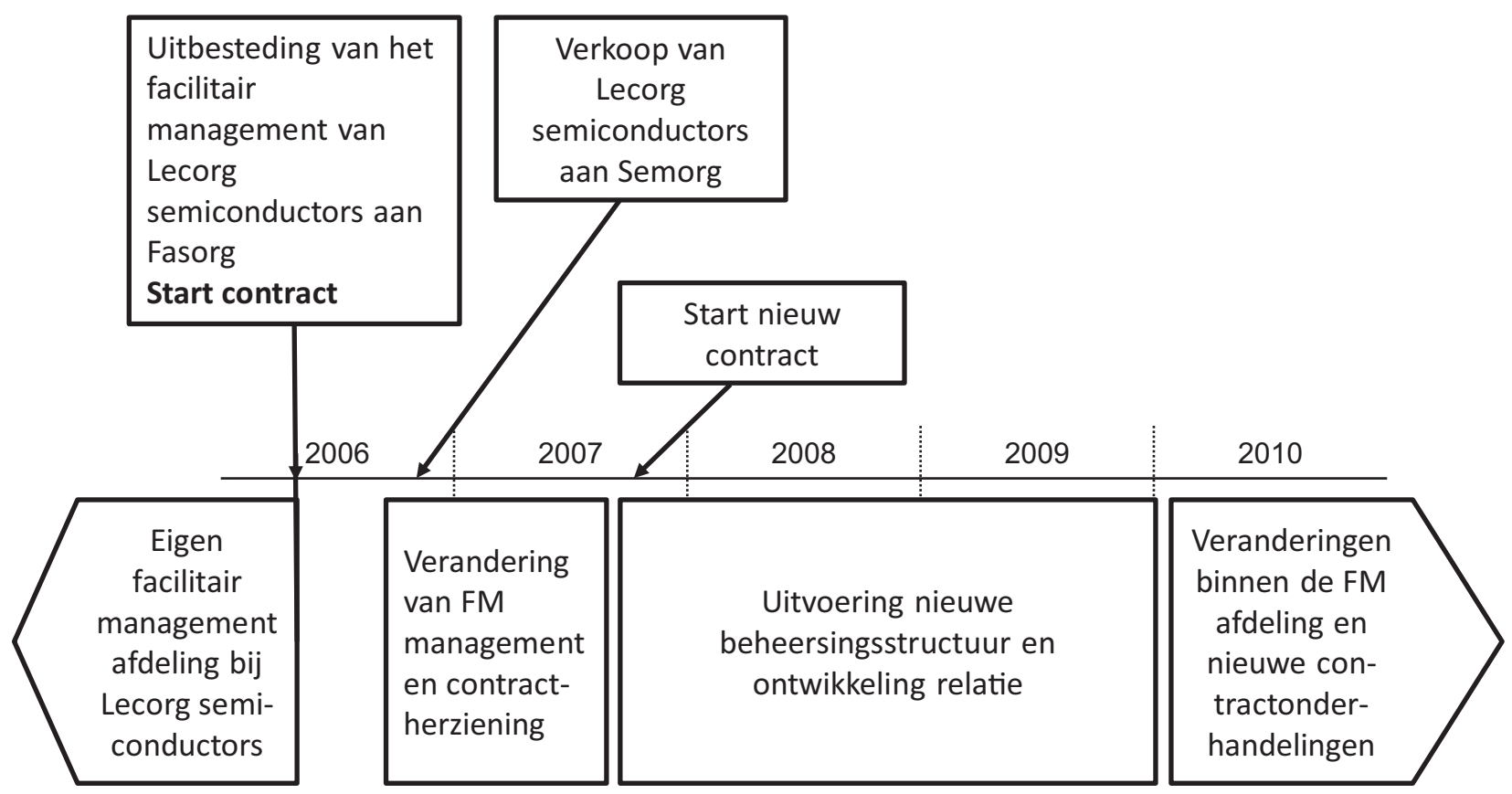

Dit artikel onderzoekt hoe vanuit een relationeel perspectief contracten, beheersingsstructuren en vertrouwen worden vormgegeven en veranderen. Een casestudie is hiervoor een geschikte methode, omdat hiermee diepgaand een specifieke context, gedurende een periode kan worden gevolgd. Volgens Caglio and Ditillo (2008) is het met name van belang om een relatie vanuit zowel de klant als de leverancier te onderzoeken met de nadruk op de processen en dynamiek, aangezien relaties veranderen met gevolgen voor de manier waarop beheersing en vertrouwen zich ontwikkelen. In dit onderzoek wordt hieraan gehoor gegeven.

Het doel is te onderzoeken hoe het contract en de hierin opgenomen beheersingsstructuren ontstaan in het netwerk dat wordt bestudeerd en hoe ze performatief kunnen zijn. In het bijzonder gaat het erom te begrijpen hoe het contract en de daarin opgenomen beheersingsstructuren zich verhouden tot de ontwikkeling en bestendiging van vertrouwen. Het startpunt voor dit onderzoek was vlak nadat de partijen de overeenkomst hadden herzien en het contracteringsproces en de redenen voor de herziening nog vers in het geheugen van de participanten lagen. Op basis van de documenten en interviews, kon de contracteringsfase worden gereconstrueerd en ontstond de mogelijkheid om te analyseren hoe het contract en de beheersingsstructuren onverwachte performatieve effecten in het netwerk hadden veroorzaakt. 
Figuur 3. Hiërarchische posities van de geïnterviewden binnen Semorg en Fasorg en hun connecties.

Semorg

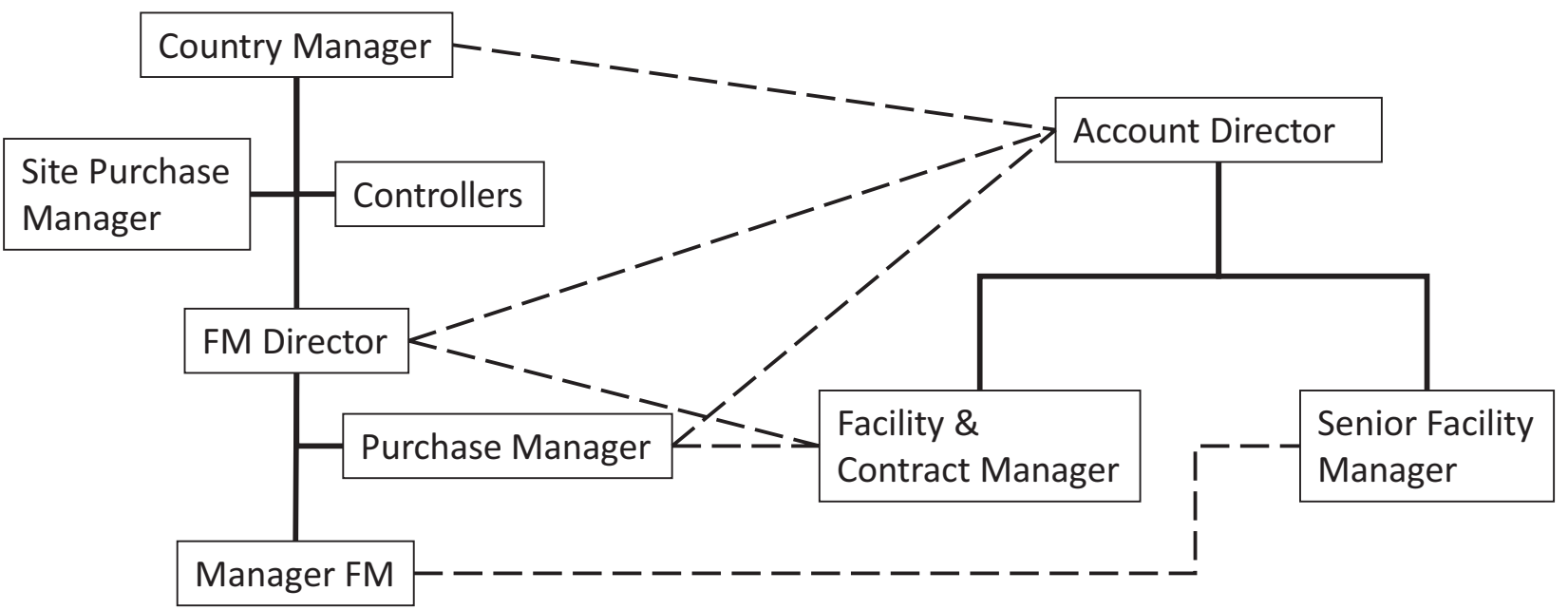

De geïnterviewden werden geselecteerd op basis van hun betrokkenheid bij de facilitaire uitbestedingsrelatie. Figuur 3 toont de hiërarchische positie van de geïnterviewden. De gestippelde lijnen geven de contacten op de verschillende niveaus tussen de twee organisaties aan. Wij hebben 23 interviews afgenomen met 19 personen. Er zijn dertien Semorg en vier Fasorg managers op verschillende hiërarchische niveaus en in verschillende afdelingen geïnterviewd, zoals Facilities Management, Inkoop, Finance \& Accounting en Productie. Twee managers zijn dubbel geïnterviewd. Daarnaast zijn twee managers van twee verschillende leveranciers van de facilitaire diensten geïnterviewd. Twee interviews zijn georganiseerd als algemene feedback-bijeenkomsten tussen het onderzoeksteam en de belangrijkste spelers van Semorg. Tijdens de eerste feedback-bijeenkomst werd door het onderzoeksteam informatie gegeven over het onderzoeksdoel, de onderzoeksvragen, planning en methoden. Wij kregen tijdens de bijeenkomst informatie over Semorg's uitbestedingsstrategie. Tijdens de tweede bijeenkomst zijn de resultaten van de eerste ronde van interviews gepresenteerd en besproken samen met het onderzoeksteam, de Facility Management Director en Purchase Manager. Overige geanalyseerde data zijn de SLA's, de roadmap-documenten en kwartaalrapportages.

\section{Case studie: Ontwikkeling van een facilitaire managementrelatie}

Een contract is niet meer dan een stapeltje juridische documenten. Dit leerde ik toen ik zaken deed in Azië. Eén van mijn Chinese partners zei toen tegen mij: "Hoe meer papierwerk, hoe minder vertrouwen we hebben en hoe minder het werkt."

- Country Manager Semco
Dit onderzoek richt zich op drie fasen in de ontwikkeling van de relatie tussen Semorg en Fasorg: (1) Het oorspronkelijke contract afsluiten - onderhandelen en besluitvorming op afstand - het contract werkte echter niet zoals gewenst en veroorzaakte de behoefte aan hercontractering; (2) Contractherziening - de opbouw van vertrouwen; (3) Verdere ontwikkelingen in de relatie en de performativiteit van de beheersingsstructuren. De volgende paragrafen zijn gestructureerd rond deze drie fasen

\subsection{Fase 1: Het oorspronkelijke contract - onderhan- delen en besluitvorming van een afstand}

De eerste fase in de relatie wordt gekenmerkt door het afsluiten van het contract tussen Fasorg en Lecorg en problemen met de uitvoering van het oorspronkelijke contract.

Lecorg's strategie was om alles wat niet werd beschouwd als kernactiviteit uit te besteden. Deze strategie leidde ook tot de beslissing om het facilitair management uit te besteden, wat resulteerde in een contract met Fasorg. Het eerste contract dat werd getekend tussen Fasorg en Lecorg had niet de zegen van de managers van Semorg. Ze wisten dat Lecorg van plan was om Semorg te verkopen en vonden dat deze beslissing zou zorgen voor te veel verandering in één keer.

Semorg vond dat Lecorg de beslissing om uit te besteden aan het management van Semorg had moeten overlaten. Na de ondertekening van het contract tussen Lecorg en Fasorg was er veel weerstand tegen de uitbesteding. Fasorg's account director kreeg nauwelijks steun van Semorg's facility managers.

In het contract waren beheersingsstructuren opgenomen zoals Key Performance Indicators (KPI's) en prikkels voor besparingen. De managers die betrokken waren bij de operationele activiteiten vonden echter dat het contract niet veel duidelijkheid verschafte in wat er bereikt 
moest worden en door wie. Een facility manager van Semorg verwoordde het als volgt:

Ik denk dat het niet voor iedereen duidelijk was wat de doelen waren, hoe het gedaan moest worden en door wie (Manager FM Semorg).

Onenigheid tussen Fasorg en Semorg ontstond ook door clausules in het contract. Bijvoorbeeld, besparingen die door Fasorg gerealiseerd werden kwamen voor $80 \%$ ten goede aan Semorg en slechts voor 20\% aan Fasorg. Het contract en de opgenomen beheersingsstructuren bleken geen bron van stabiliteit en voorspelbaarheid. In plaats van dat het zorgde voor het stabiliseren van de relatie werd het contract een bron van instabiliteit en genereerde het discussies en conflicten. FM director gaf uitleg bij een aantal problemen in relatie met het contract:

Het contract werd er door Lecorg van bovenaf doorgedrukt, maar er werd niet duidelijk gemaakt wat verwacht werd van Fasorg. Semorg was op dat moment niet in staat om te bepalen wat te verwachten van de leverancier en waar de focus lag (FM director, Semorg).

In een conflict kunnen we zeggen oké we gaan nog eens kijken naar het contract. Dat is wat ik een paar maanden geleden deed, omdat we een discussie hadden over wat een besparing is. Je kunt daar een lange discussie over voeren. Is het een kostenreductie of is het gewoon het verminderen van de hoeveelheid werk? Bijvoorbeeld het sluiten van een gebouw, is dat een besparing? [...] Nee dat is geen besparing, dat is een verandering van het serviceniveau. We hadden hier een zeer lange discussie over (FM director, Semorg).

Blijkbaar was het contract dus niet duidelijk en zorgde het voor discussie en debat. De managers van Semorg committeerden zich niet aan het contract, vooral vanwege onvrede over de beslissing van het senior management van Lecorg om het beheer van de facilitaire diensten uit te besteden. Het was niet hun beslissing om uit te besteden, zij hadden niet deelgenomen aan het contracteringsproces en ze ervoeren het begin van de relatie als een strijd.

In 9 van de 10 gevallen is het een beslissing van het management op het hoogste niveau. Meestal boven mijn niveau en in het geval van Fasorg was iedereen in onze divisie er tegen, met inbegrip van de FM directeur. Ik was er ook tegen, maar het was de filosofie van Lecorg in het algemeen, dus het gebeurde (FM Manager, Semorg).

Hoewel er dus een expliciet contract bestond, was er een gebrek aan steun en vertrouwen bij beide partijen. De aanvankelijk contracterende partij, Lecorg, dacht dat het voldoende aandacht had besteed aan de verschillende belangen, maar dat werd niet ondersteund door de managers die betrokken waren bij de operationele processen. Semorg had niet deelgenomen aan de selectie van partners en het onderhandelingsproces dat Lecorg en Fasorg samenbracht. Semorg-managers konden zich daardoor ook moeilijk volledig committeren aan de dagelijkse activiteiten. Het contract leidde niet tot de orde en stabiliteit die door de oorspronkelijke contracteerders werd nagestreefd. Het contract en de opgenomen beheersingsstructuren waren niet performatief in de zin dat ze vertrouwen produceerden. Integendeel, het contract veroorzaakte conflicten met betrekking tot de toewijzing van taken, verantwoordingsvraagstukken en afrekensystemen. Het contract in combinatie met de ontevreden managers veranderde de relatie in een niet-coöperatieve relatie. Zoals één van de managers zei:

Je bouwt een huis op een fundament, het contract. Als het fundament niet goed is, moet je niet beginnen met de bouw van een huis. Dat is wat we hebben geleerd: doe dat niet " (Purchase Manager, Semorg).

Uit de samenwerkingsrelatie stappen was geen optie voor het topmanagement van Semorg. Het oorspronkelijke contract besloeg een periode van vier jaar en het verbreken van het contract zou vervelende juridische gevolgen kunnen hebben. Bovendien werden de oorspronkelijke redenen om uit te besteden, zoals het verbeteren van flexibiliteit en (vooral) het verlagen van de kosten, nog steeds onderschreven door het topmanagement van Semorg. De concurrentie in de halfgeleiderindustrie was stevig en een jaarlijkse daling van de kosten was een noodzakelijke voorwaarde om te overleven. Ook al waren niet alle managers van Semorg ervan overtuigd dat de gewenste kostenbesparingen zouden worden gerealiseerd binnen deze samenwerkingsrelatie, ze vonden het ook niet verstandig om de overeenkomst te beëindigen.

Het contract en de daarin opgenomen beheersingsinstrumenten konden de mogelijke problemen van de samenwerking dus niet eenduidig voorkomen. De operationele zaken functioneerden niet zoals bedoeld en de betrokkenen konden geen vertrouwen ontlenen aan het contract en de beheersingsstructuren. Het tegendeel was waar, want het contract en de daarin opgenomen beheersingsstructuren produceerden juist instabiliteit en onvoorspelbaarheid. Het contract was echter wel performatief in de zin dat het zorgde voor een hercontracteringsproces. Door de juridische en economische consequenties van een beëindiging van de relatie voor Semorg, moest Semorg het contract met Fasorg wel heronderhandelen om het beste uit de relatie met Fasorg te halen.

\subsection{Fase 2: Contract herziening - de opbouw van ver- trouwen}

Het (oorspronkelijke) contract was getekend voor vier jaar. Toen ik hier begon, zijn we begonnen om het contract te herzien. De afgesproken periode veranderde niet, maar we veranderden sommige details. [...] We brachten een aantal nuances aan voor een betere samenwerking om samen te werken aan een, uh ... één doel (Purchase Manager, Semorg).

Het hercontracteringproces werd beschouwd als een manier om te werken aan de samenwerkingsrelatie. Een Semorg-manager legde dit als volgt uit:

Ze moesten het contract echt herzien, want het contract geeft toch aan hoe organisaties met elkaar omgaan en hoe ze zich gedragen (Purchase Manager, Semorg).

Op de vraag of de relatie had kunnen worden verbeterd zonder het afsluiten van een nieuw contract, antwoordde een andere manager: 
Zou kunnen ... maar uiteindelijk komt het er toch op neer dat het contract de interactie en de zakelijke manier van werken tussen de twee bedrijven bepaalt. Het contract formaliseert de manier waarop je zou moeten werken. In de praktijk blijft de overeenkomst uiteraard meestal in de kast en doe je gewoon je dagelijkse werk (FM Manager, Semorg).

Het contract is daarmee dus veel meer dan een afstandelijke oplossing voor verschillen in belangen en veel meer dan een bescherming tegen potentieel opportunistisch gedrag. Blijkbaar hadden de managers ook behoefte aan het delen van informatie, zoals blijkt uit de volgende beschrijving:

We hadden een herziening, een contractherziening met het management hier en we zeiden dat we het nodig vonden om bepaalde zaken te delen; we vinden het nodig om onze gedachten te delen over het contract en de resultaten van het contract (Purchase Manager, Semorg).

Door de interacties tussen de partijen tijdens het hercontracteringsproces werd getracht de samenwerking te verbeteren. Het oorspronkelijke contract was reden om te komen tot een proces van hercontractering en tijdens dit proces ontstonden nieuwe en belangrijke interacties tussen de betrokkenen.

Om de samenwerking te verbeteren en nieuw leven in te blazen had het topmanagement van Semorg besloten om een nieuwe FM-director te benoemen en tegelijkertijd werd een nieuwe country manager aangesteld, Deze nieuwe benoemingen werden gezien als een belangrijke ontwikkeling in de relatie. Het was een duidelijk en doelgericht teken (in termen van Lindenberg (2000) een relationeel signaal) naar Fasorg dat Semorg was gecommitteerd aan de relatie en dat Fasorg werd vertrouwd.

De nieuwe FM-director wilde een relatie opbouwen op basis van wederzijds respect en vertrouwen. Het volgende citaat is een voorbeeld van zijn coöperatieve houding en geeft aan welke relationele signalen hij afgeeft.

We hebben een gemeenschappelijke overeenkomst, waarover we het beide eens zijn. Wij, als Semorg, eisen niet een besparing van $€ 500.000$ en zeggen vervolgens zoek maar uit hoe jullie het doen Nee, je moet dit doen in overleg. Nee zij komen ook met ideeën en het is te gemakkelijk om dat af te doen als een slecht idee. Nee, we hebben allebei de verantwoordelijkheid voor het realiseren van besparingen. We moeten de juiste kansen op besparingen definiëren (FM director, Semorg).

De contractherziening werd door het lokale management gedaan. Door middel van waardevolle interacties werden waarden en ambities gedeeld en werd het contract weer gezien als een gezamenlijke inspanning. Zo kon aan het contract weer vertrouwen worden ontleend. Dit betekende overigens niet dat de functionele afstemming van belangen verder geen rol meer speelde. Dat deed het wel zeker:

In het contract hebben we prikkels en sancties opgenomen, omdat Fasorg over een periode van twee jaar de kosten naar beneden moet brengen. Als ze geen kostenbe- sparingen kunnen realiseren moeten ze een boete betalen. Als ze het beter doen dan delen zij in de extra kostenbesparingen. Dat is een soort bonus-malussysteem (Country Manager, Semorg).

We hebben de relatie omgebogen in een samenwerkingsverband. Dit is wat we allebei wilden, maar we hadden de juiste meet- en afrekensystemen nodig om dit te realiseren (FM Director, Semorg).

Ook een Fasorg manager erkent dat het vertrouwen groeide tijdens de contractonderhandelingen:

$\mathrm{Na}$ het afsluiten van het nieuwe contract was er veel meer vertrouwen, veel meer samenwerking. In mijn team is er bijvoorbeeld iemand die verantwoordelijk is voor de besparingen, maar we hebben ook een Semorg partner die verantwoordelijk is voor besparingen en ze werken nauw samen (Account Director, Fasorg).

Het contract kreeg gedurende het veranderingsproces dus een belangrijkere rol en door de interacties tijdens de hercontractering groeide het vertrouwen in de relatie. Het contract mobiliseerde de betrokkenen om samen te werken. Volgens de betrokken partijen kwam er bovendien een fatsoenlijke afstemming tussen de verschillende belangen tot stand. Dit kwam tot stand in een relationeel netwerk en het ging in samenhang met het opbouwen van vertrouwen.

\subsection{Fase 3: Verdere ontwikkelingen van de relatie en de performativiteit van de beheersingsstructuren}

$\mathrm{Na}$ de hercontracteringsperiode kon een derde fase worden onderscheiden waarin, tegen de achtergrond van de hernieuwde overeenkomst, de facility managementpraktijken plaatsvonden. Zowel Semorg als Fasorg waren er op gericht om te werken aan de relatie op basis van het vernieuwde contract. Er werd vertrouwen aan het contract toegekend en de partijen hadden zich gecommitteerd aan de relatie. De relatie was echter nog jong en kwetsbaar. De hercontractering was vooral gedaan door Semorg's FM director en Fasorg's account director. Fasorg's account director maakte concrete plannen waarin hij liet zien dat hij op de hoogte was van de wensen van de klant. Hij maakte een businessplan dat afgestemd was op Semorg's business plan. Hiermee liet hij zien dat beide organisaties goed op elkaar afgestemd waren.

Je moet laten zien dat je bereid bent mee te werken. Dus we hebben bijvoorbeeld voor dit jaar een jaarplan, een business plan, gemaakt en we hebben dat vergeleken met het business plan van Semorg en dat was voor 80-85\% hetzelfde. Dus dat betekent dat we begrijpen wat ze willen en dat we de mogelijkheden hebben om te doen wat ze willen (Account Director, Fasorg).

De business cases waren een signaal dat Fasorg competent was en toonden aan dat de partijen elkaar begrepen. Fasorg gaf ook relationele signalen af dat het de continuiteit van de relatie waardeerde. Vanuit een rationeel perspectief kan dit worden geduid als een poging om dik ver- 
trouwen op te bouwen. Fasorg straalde vertrouwen uit met als doel vertrouwd te worden, zodat de uitbestedingsrelatie echt zou kunnen uitgroeien tot een samenwerkingsrelatie. Vertrouwen ging steeds meer circuleren binnen de relatie.

Ik heb je een voorbeeld gegeven van hoe de relatie veranderde van een papieren contract en een top-down initiatief naar een meer coöperatieve relatie, waarbij onderweg het vertrouwen werd hersteld (Purchase Manager, Semorg).

Openhartige gesprekken en het gezamenlijk opzetten van projecten, resulteerden in besparingen. Beide partijen waren gemotiveerd om deel te nemen aan deze projecten. Ze veranderden ook de manier waarop vergaderingen, die een onderdeel waren van de besturingsstructuur, werden ingezet; een verandering die beide partijen als positief ervoeren. Oorspronkelijk werd iedere week één uur vergaderd. Deze bijeenkomsten waren vaak te kort om de problemen waarmee zij geconfronteerd werden adequaat op te lossen. De nieuwe overlegstructuur had een lagere frequentie (eenmaal per maand), maar duurde een volle middag.

We hebben dit nu twee maanden gedaan en eigenlijk ben ik er heel blij mee. Nu hebben we de tijd om een hele middag grondig op een onderwerp in te gaan en we hebben tijd om echt te discussiëren. In de oude structuur werd het hele uur vaak besteed aan operationele zaken en kwam je nooit echt tot het probleem (FM director, Semorg).

$\mathrm{Na}$ de hercontractering vonden de gesprekken met Fasorg over de beheersingsmaatregelen plaats in een coöperatieve sfeer. De interactief ontwikkelde beheersingsmaatregelen omvatten een bonus-malussysteem, een prestatiemanagementsysteem met KPI's, maand- en kwartaalrapportages en een vergaderstructuur.

De beheersingsmaatregelen bevatten drie KPI's: Fasorg prestaties, klanttevredenheid en kwaliteit van de leveranciers. De maandelijkse contractbesprekingen en de KPI's waren belangrijke beheersingsmaatregelen voor het besturen van de dagelijkse operaties. Op een coöperatieve manier werden nieuwe KPI's ontwikkeld en tegelijk mobiliseerden de vergaderstructuur en de KPI's de managers om de relatie om te zetten in een samenwerkingsverband waarbinnen vertrouwen bestaat.

Elk kwartaal doen ze verslag van hun prestaties. [...] We noemen onze 'voeten-op-de-tafel-sessie'. Wat is je gevoel? Wat is je probleem? Je hebt een probleem met mij? Wat is het probleem? Laten we dit bespreken. Gewoon werken aan de relatie (FM director, Semorg).

De KPI's waren niet ontworpen en geïmplementeerd op een afstand, maar werden interactief gevormd door de betrokkenen in het relationele netwerk. De KPI's genereerden debatten en discussies. Conflicten ontstonden op het moment dat managers begonnen te twijfelen aan de representatieve kwaliteiten van de KPI's. Als gevolg daarvan werden KPI's veranderd. Discussies en debatten over de prestatie-indicatoren versterkten het vertrouwen dat Semorg en Fasorg in elkaar hadden. De FM-manager van Semorg was hierbij overtuigd van de integriteit van Fasorg in het verstrekken van de cijfers:
Ondanks problemen en verbetermogelijkheden moet je dit zien als een soort van samenwerking. Het is een langetermijnrelatie; je gaat er vol voor en als je dat niet wilt moet je er ook niet aan beginnen. Fasorg moet niet streven naar de 'quick win' en ook Semorg niet. Je moet een langetermijndoel voor ogen hebben en als je begint met manipuleren of fraude dan kun je elkaar nooit meer vertrouwen (FM Manager, Semorg).

Elke maand werd door de partijen besproken hoe de afgesproken kostenbesparingen konden worden gerealiseerd. Deze besprekingen werden een integraal onderdeel van de maandelijkse vergaderingen waarin ook de beheersingsstructuren zelf werden besproken.

Er is een zeer open discussie. Elke maand komt FM director samen met Fasorg. Hoeveel hulp heb je nodig bij de projecten? Dus de discussie gaat erover hoe we al de kostenbesparingen samen kunnen bereiken (Country Manager, Semorg).

De prestaties van Fasorg werden gemeten met een prestatiemeetsysteem dat was gebaseerd op 'open-book accounting'. Managers van Semorg hadden volledige toegang tot de boeken. Fasorg's account director legt uit hoe ze transparantie creëerden voor Semorg en hoe inzichtelijkheid van cijfers zorgde voor vertrouwen in het netwerk van de uitbestedingsrelatie:

De purchase manager van Semorg had het gevoel dat het open-boeksysteem een black box was waar iets in ging en iets uit ging, maar hij wist niet wat er in de black box gebeurde. Ik nodigde hem uit om mee te gaan naar mijn bedrijf en nodigde een aantal mensen uit van Finance, van Performance en van Compliance en zij gaven een compleet overzicht van de inhoud van de black box en lieten zien hoe de cijfers tot stand komen. We hadden een sessie van 2 uur en hij was helemaal tevreden, ja, want we waren open en volledig transparant. Het is uiteindelijk hun geld en wij moeten zorgen dat er iets goeds mee gebeurt (Account Director, Fasorg).

Ook op de ander locatie van Semorg in Nederland gaf de FM-manager blijk van een soortgelijke ervaring met Fasorg. Op deze locatie waren slechts kantoren en geen fabrieken en Fasorg beheerde alle facilitaire diensten. De lokale FM-manager moest wennen aan de nieuwe manier van werken, maar ervoer geen problemen:

Ik denk dat we veranderd ... uh ... ik veranderd ben in een demand manager en zij doen de dagelijkse operationele zaken en dat doen ze erg goed. We hebben nu een één-op-éénorganisatie (FM manager, Semorg).

Deze fase laat zien dat de structuren helpen bij het genereren van positieve verwachtingen over de verdere ontwikkeling van de relatie. De beheersingsstructuren zijn niet statisch en instrumenteel in het stroomlijnen van belangen of het beperken van risico's, maar de beheersingsstructuren veranderen zelf en veranderen de relatie in een samenwerking. De besprekingen (met name de maandelijkse bijeenkomsten) en de KPI's waren performatief doordat ze de ontwikkeling van de samenwerkingsrelatie beïnvloedden. 


\section{Discussie en conclusie}

De Semorg-managers die verantwoordelijk waren voor de dagelijkse activiteiten, waren niet betrokken bij de oorspronkelijke contractonderhandelingen. Voor deze managers bood het contract en de daarin opgenomen beheersingsstructuren dan ook geen oplossing. Met name in het begin van de contractuele periode sloot het contract niet aan op de manier van werken in Semorg en werd dan ook niet als ondersteunend gezien. Het contract gaf hen geen vertrouwen in een goede relatie. Wat er wel gebeurde, was dat het contract de aanleiding vormde voor een onverwachte wending in het verloop van de uitbestedingsrelatie. Het loutere bestaan van het contract dwong de managers om de relatie te laten werken. Het simpelweg verbreken van het contract was juridisch zo goed als onmogelijk en zou schadelijke gevolgen hebben voor het bedrijf, dus dat was geen optie. Hercontracteren was echter wel een optie. Deze hernieuwde onderhandelingen leverden een aangepaste overeenkomst op die een rol ging spelen in een netwerk van relaties waar vertrouwen onderdeel van kon worden en waarbinnen de relatie zich kon ontwikkelen. Aan het nieuwe contract kon daardoor wel vertrouwen worden ontleend.

In de loop van de relatie werden nieuwe beheersingsstructuren ontwikkeld, bonus-malussystemen, KPI's, open-boeksystemen en maand- en kwartaalrapportages. Deze werden een deel van het relationele netwerk door middel van discussies en leidden tot een wederzijds begrip bij het uitvoeren van lopende taken. De beheersingsstructuren en de KPI's werden gevormd binnen de relatie in plaats van gemaakt en uitgevoerd op afstand. Hierdoor droegen ze bij aan het genereren van begrip in het relationele netwerk. Zij waren daardoor in het bijzonder van belang bij het in gang zetten van de ontwikkeling van een vertrouwensrelatie en een samenwerkingsverband.

Het relationele perspectief in dit artikel laat zien hoe het contract en de beheersingsstructuren een belangrijke rol vervullen in de uitbestedingsrelatie en hoe ze de relatie kunnen vormen en zelf ook vorm krijgen binnen het netwerk van interacties in de relatie. De contracten en besturingsstructuren zijn niet slechts een uitkomst van menselijk handelen, maar de mensen worden hierdoor eveneens gemobiliseerd en in een bepaalde richting gestuurd. Zij spelen daarmee een belangrijke rol in de ontwikkeling van de uitbestedingsrelatie (zie ook Zahirul-Hassan et al. 2016).

In het relationele perspectief is vertrouwen een gevolg en niet iets dat al ex ante bestaat. Vertrouwen ontstaat door het proces van contracteren en het bespreken van beheersingsstructuren. Zo wordt vertrouwen operationeel in het netwerk. Dit is niet iets dat vooraf en op afstand kan worden beslist. Het is niet een kwestie van simpelweg vooraf bepaalde kenmerken van vertrouwen selecteren, zoals bijvoorbeeld contractueel vertrouwen, competentievertrouwen of goodwillvertrouwen (Sako 1992) gevolgd door een rechttoe rechtaan implementatie hiervan. Vanuit een relationeel perspectief circuleert vertrouwen in de relatie en is daarmee niet programmeerbaar of voorspelbaar. Uiteraard is vertrouwen een belangrijk streven en de afwezigheid ervan is problematisch (Mouritsen and Thrane 2006). Verantwoordelijke managers zullen daarom rationeel reageren op dergelijke ontwikkelingen door bijvoorbeeld het contract te veranderen of door het aannemen van nieuwe coöperatieve managers op belangrijke posities in het netwerk.

Vanuit een relationeel perspectief zijn contracten en beheersingsstructuren niet de uitkomst van rationele beslissingen van managers op afstand die zicht hebben op eenduidig geformuleerde problemen, zoals bijvoorbeeld coördinatieproblemen en toe-eigeningsproblemen (Dekker 2004; Gulati and Singh 1998) en die kiezen voor de bijpassende kant-en-klare oplossingen, zoals bijvoorbeeld monitoren, benchmarking, prikkels en sancties. Contracten en beheersingsstructuren zijn niet een eindpunt, maar juist het startpunt. Ze produceren geen vertrouwen, maar geven de mogelijkheid om er vertrouwen aan te ontlenen.

- Dr. R.A. Minnaar is universitair hoofddocent Management Accounting en Control aan de Nyenrode Business Universiteit

- Prof. dr. P.M.G. van Veen-Dirks is hoogleraar Management Accounting aan de Rijksuniversiteit Groningen

- Dit artikel is een verkorte bewerking van het artikel van Minnaar et al. (2017).

\section{Literatuur}

- Cäker M (2008) Intertwined coordination mechanisms in interorganizational relationships with dominated suppliers. Management Accounting Research 19(3): 231-251. https://doi.org/10.1016/j. mar.2008.06.003

- Caglio A, Ditillo A (2008) A review and discussion of management control in inter-firm relationships: Achievements and future directions. Accounting, Organizations and Society 33(7-8): 865-898. https://doi.org/10.1016/j.aos.2008.08.001

- Callon M (1998) The laws of the markets. London: Blackwell.
- Callon M (2007) What does it mean to say that economic is performative? In: Mackenzie D, Muniesa F, Siu L (Eds) Do economists make markets? on the performativity of economics. NJ: Princeton University Press, Princeton, 311-357.

- Chua WF, Mahama H (2007) The effect of network ties on accounting controls in a supply alliance: Field study evidence. Contemporary Accounting Research 24(1): 47-86. https://doi.org/10.1506/7156201W-1290-83H4 
- Chua WF, Mahama H (2012) On theory as a 'deliverable' and its relevance in 'policy' arenas. Critical Perspectives on Accounting 23(1): 78-82. https://doi.org/10.1016/j.cpa.2011.05.001

- Dekker HC (2004) Control of inter-organizational relationships: evidence on appropriation concerns and coordination requirements. Accounting, Organizations and Society 29(1): 27-49. hthttps://doi. org/10.1016/S0361-3682(02)00056-9

- Emsley D, Kidon F (2007) The relationship between trust and control in international joint ventures: Evidence from the airline industry. Contemporary Accounting Research 24(3): 829-858. https://doi. org/10.1506/car.24.3.7

- Gulati R, Singh H (1998) The architecture of cooperation: Managing coordination costs and appropriation concerns in strategic alliances. Administrative Science Quarterly 43(4): 781-814. https://doi. org/10.2307/2393616

- Håkansson H, Lind J (2004) Accounting and network coordination. Accounting, Organizations and Society 29(1): 51-72. https://doi org/10.1016/S0361-3682(02)00058-2

- Klein Woolthuis R, Hillebrand B, Nooteboom B (2005) Trust, contract and relationship development. Organization Studies 26(6): 813-840. https://doi.org/10.1177/0170840605054594

- Langfield-Smith K, Smith D (2003) Management control systems and trust in outsourcing relationships. Management Accounting Research 14(3): 281-307. https://doi.org/10.1016/S1044-5005(03)00046-5

- Lindenberg S (2000) It takes both trust and lack of mistrust: The workings of cooperation and relational signaling in contractual relationships. Journal of Management \& Governance 4(1-2): 11-33. https://doi.org/10.1023/A:1009985720365

- Lui SS, Ngo H (2004) The role of trust and contractual safeguards on cooperation in non-equity alliances. Journal of Management 30(4): 471-485. https://doi.org/10.1016/j.jm.2004.02.002

- Mahama H, Chua WF (2016) A study of alliance dynamics, accounting and trust-as-practice. Accounting, Organizations and Society, 51: 29-46. https://doi.org/10.1016/j.aos.2016.04.004

- Minnaar RA, Vosselman E, Van Veen-Dirks PMG, Zahir-ul-Hassan MK (2017) A relational perspective on the contract-control-trust nexus in an interfirm relationship. Management Accounting Research 34: 30-41. https://doi.org/10.1016/j.mar.2016.07.003

- Mouritsen J, Thrane S (2006) Accounting, network complementarities and the development of inter-organisational relations. Accounting, Organizations and Society 31(3): 241-275. https://doi. org/10.1016/j.aos.2005.04.002
- Nooteboom B (1996) Trust, opportunism and governance: A process and control model. Organization Studies 17(6): 985-1010. https:// doi.org/10.1177/017084069601700605

- Nooteboom B (2002) Trust: forms, foundations, functions, failures and figures. Cheltenham: Edward Elgar Publishing. https://doi. org/10.4337/9781781950883

- Revellino S, Mouritsen J (2015) Accounting as an engine: The performativity of calculative practices and the dynamics of innovation. Management Accounting Research 28: 31-49. https://doi. org/10.1016/j.mar.2015.04.005

- Sako M (1992) Prices, quality, and trust: inter-firm relations in Britain and Japan. Cambridge University Press, Cambridge. https://doi. org/10.1017/CBO9780511520723

- Thrane S, Hald KS (2006) The emergence of boundaries and accounting in supply fields: The dynamics of integration and fragmentation. Management Accounting Research 17(3): 288-314. https:// doi.org/10.1016/j.mar.2006.06.001

- Tomkins C (2001) Interdependencies, trust and information in relationships, alliances and networks. Accounting, Organizations and Society 26(2): 161-191. https://doi.org/10.1016/S0361-3682(00)00018-0

- Tsamenyi M, Qureshi AZ, Yazdifar H (2013) The contract, accounting and trust: A case study of an international joint venture (IJV) in the United Arab Emirates (UAE). Accounting Forum 37(3): 182195. https://doi.org/10.1016/j.accfor.2012.09.004

- Van der Kolk B, Ter Bogt HJ, Van Veen-Dirks PMG (2015) Constraining and facilitating management control in times of austerity: Case studies in four municipal departments. Accounting, Auditing \& Accountability Journal 28(6): 934-965. https://doi.org/10.1108/AAAJ-03-2014-1660

- Van Veen-Dirks PMG, Verdaasdonk PJA (2009) The dynamic relation between management control and governance structure in a supply chain context. Supply Chain Management: An International Journal 14(6): 466-478. https://doi.org/10.1108/13598540910995237

- Vosselman EGJ, Van der Meer-Kooistra J (2009) Accounting for control and trust building in interfirm transactional relationships. Accounting, Organizations and Society 34(2): 267-283. https://doi. org/10.1016/j.aos.2008.04.002

- Zahir-ul-Hassan MK, Minnaar RA, Vosselman EGJ (2016) Governance and control as mediating instruments in an inter-firm relationship: towards collaboration or transactions? Accounting and Business Research 46(4): 365-389. https://doi.org/10.1080/00014788.2015.1123601 